\title{
Hygiene and Manufacturing Practices, Interagency Collaboration, and a Proposal for Improvement: A Case Study of Community Food Enterprise in Thailand
}

\author{
Sudarin Rodmanee and Wen-Chi Huang, Member, IACSIT
}

\begin{abstract}
This study reports the current hygiene and manufacturing practices adopted in a women's community enterprise (WCE) for processing an herbal seasoning product in Sakon Nakhon Province, Thailand. A multidisciplinary team comprised researchers and inspectors from government agencies was formed to conduct interviews and evaluations by using a good manufacturing practice (GMP) checklist. The results showed that the WCE did not pass the GMP standard. We formed an action plan to identify the requirements for GMP implementation. Non-compliance factors were delegated to each stakeholder for action and implementation. To achieve an action plan, the participation of every stakeholder is crucial.
\end{abstract}

Index Terms-Good manufacturing practices (GMP), inter-agency collaboration, community enterprise.

\section{INTRODUCTION}

In Thailand, community enterprises can be defined as small and micro community enterprises (SMCEs), which operate their businesses on a small scale with self-employed members and a small amount of capital [1]. Their business operation is related to the community's economic and social circumstances, and people using local and natural material, simple technology, and a local labor force [2]. The 2005 Small and Micro Enterprise Extension Act was promulgated to encourage entrepreneurship and rejuvenate the Thailand grassroots economy. By helping small community businesses become legal entities, the act improved opportunities for these enterprises to receive recognition as well as various types of government support.

Two main government agencies in the Ministry of Agriculture and Cooperatives (MOAC) are involved in supporting and promoting community enterprises, which are the Department of Agricultural Extension (DOAE) and the Agricultural Land Reform Office (ALRO), in addition to various vocational and agricultural colleges under the supervision of the Ministry of Education. These agencies provide and coordinate technical and financial support for community enterprises, such as with the provision of training programs, basic infrastructure, equipment, and low interest loans.

Food safety has been at the forefront of public attention in Thailand. Food safety and quality programs are increasingly

Manuscript received December 15, 2012; revised April 30, 2013.

Sudarin Rodmanee is with Department of Tropical Agriculture and International Cooperation, National Pingtung Unversity of Science and Technology, Nonthaburi, Thailand (e-mail: sudarin@hotmail.com). focusing on a farm-to-fork approach to improve food safety. Measures to ensure hygienic conditions during food processing are mandatory to obtain a safe food product. Food hygiene and good manufacturing practices (GMPs) are the first measure to be adopted by food industries to guarantee the safety and compliance of food products to specific regulations. Moreover, GMPs are essential for implementing management systems such as Hazard Analysis and Critical Control Points (HACCP) [3].

In response to the recent trend of food safety in the country, the Thai government has placed considerable emphasis on food safety improvement policies. The Ministry of Public Health (MOPH) is responsible for the Food Safety Program. This program has been strictly implemented to maintain the standard and quality of all foods produced and consumed in Thailand [4]. In 2001, the Thai Food and Drug Administration (Thai FDA) of the MOPH issued GMP regulations; however, this presented numerous obstacles for small food businesses. Despite assistance from the government (e.g., loans with low interest rates and free consultations), GMP has still not been fully implemented nationwide. Whereas the Thai FDA is attempting to overcome the obstacles and fully implement GMP regulations for all food sectors, HACCP remain voluntary and lack a targeted timeframe for enforcement [5].

Food processing is one of the main businesses of community enterprises in Thailand. In 2008, of all 59,490 community enterprises, 8,619 were food-processing businesses [6]. In practice, these enterprises are facing a complex combination of barriers that obstruct effective GMP implementation. Limitations in investment funds and knowledge were major problems facing small-scale producers. Consequently, appropriate and practical production and quality assurance systems for small-scale producers had to be developed and tested for feasibility [7].

This study assesses the current hygiene and manufacturing practices in the community enterprise sector before GMP implementation by examining a case study of a women's community enterprise (WCE) located in Sakon Nakhon Province, which processes an herbal seasoning product.

\section{CASE Study OF THE WOMEN'S COMMUNITY ENTERPRISE}

We selected the WCE for two reasons: (a) one of the authors had worked as a researcher in the ALRO, and had substantial background knowledge regarding the WCE initiatives and the obstacles of having to comply with the GMP standard; and (b) the GMP standard has not been 
implemented in the WCE. This results in the lack of a guarantee of food safety and consumer confidence. However, the WCE business is likely to continue to grow. To sustain this growth, the improvement of food safety must be a top priority. The GMP implementation not only improves food safety but also serves to bolster the image of the enterprise, which can increase customer trust in a product.

\section{A. The Collaborative Mechanism for Hygiene}

\section{Improvement in the Women's Community Enterprise}

The goal of this study was to provide information on hygiene and manufacturing practices in the WCE before GMP implementation. To achieve this objective, cooperation among all stakeholders was required.

We conducted this study in collaboration with the WCE and statutory government agencies under two ministries: the MOAC and the MOPH.

The ALRO under the MOAC and the Provincial Offices of Agricultural Land Reform Offices (POALRO) are responsible for developing land and assisting farmers in land reform areas. For community enterprises located in land reform areas, the ALRO provides credit and production inputs. The ALRO also cooperates with related agencies to improve community enterprises according to existing local conditions in each area and their needs. At the provincial level, the POALRO is delegated by the ALRO, and is responsible for community enterprises located in each provincial land reform area.

The Thai FDA, which is under the MOPH, and the Provincial Offices of Public Health are responsible for legal food control operations, with the support of food analytical services from the Department of Medical Sciences. At the provincial level, Provincial Health Offices throughout the country are delegated by the Thai FDA to maintain the standard set by the Food Act. The Provincial Health Offices supervise food control in each provincial sector. They coordinate their policies with the Thai FDA, and its duties and responsibilities are similar to those of the Thai FDA. These provincial personnel are trained, supervised, and coordinated by the Thai FDA.

Stakeholders in this study can be categorized as operators, coordinators, and supporters. The operator is the WCE. The coordinator is the Sakon Nakhon Provincial Agricultural Land Reform Office (SNPALRO) under the ALRO and the MOAC. The four supporters include (a) the ALRO; (b) the MOAC; (c) the Sakon Nakhon Provincial Public Health Office (SNPPHO) under the MOPH; and (d) the Regional Medical Sciences Center, Udonthani, Department of Medical Sciences, under the MOPH.

The roles played by all government agencies involved are as follows: The SNPALRO is responsible for coordinating the multiple agencies discussed in this study. The ALRO and the MOAC are policymaking bodies for the supervision and control of the administration and financial management for this study. The SNPPHO provides technical advisory services, which include consultancy and training services related to the GMP standard and implementation. The Regional Medical Sciences Center, Udonthani Province, supports specialists for GMP assessment and food analytical services.
The objective of this study was to identify weaknesses that could be corrected and improved in the WCE before GMP implementation. Our researchers gained practical experience by collaborating and being involved in analyses and corrective action. The gathered information could be used as a reference for establishing systems for agency collaboration on GMP inspections for other community food enterprises.

\section{B. Characteristics of the Women's Community Enterprise}

The WCE was established in 2005 with the support of the SNPALRO, under the ALRO and the MOAC. It is located in the land reform area of Phu Phan District, Sakon Nakhon Province. Sakon Nakhon is located in the northeastern part of Thailand. It has 31 staff members, mostly women, all of whom are farmers in the land reform area of Sakon Nakhon Province. The aim of the WCE is to establish a business venture that can provide members with supplemental income after the harvesting season is over. The members combine a locally abundant resource (indigenous herbal plants) with traditional culinary wisdom to produce and sell the herbal seasoning product, Phong Nua. The members prepare the product in a member's house. The WCE does not own its own processing plant. However, it has its own production machines and brand. Each production run depends on the number of members available and the order quantity. They sell the product at the manufacturing site and in their community store. They also manufacture the product to order, and regularly participate in ALRO exhibitions, food fairs, and SMCEs' exhibitions sponsored by the government.

\section{The Herbal Seasoning Product (Phong Nua)}

Northeastern Thai food is well seasoned and strongly flavored. Most herbs play an important role in the daily lives of the northeastern community [8]. Herbs have been used as ingredients in food and medicine. Local northeastern wisdom was applied to select indigenous herbal plants and devise creative approaches for combining them into the herbal seasoning powder product Phong Nua.

Phong Nua is a combination of two words: Phong means "powder," and Nua means "appetizing"; hence, Phong Nua in Thai means "appetizing powder." It is commonly used as a seasoning powder in Northeastern Thailand, which helps generate various recipes with additional flavor. By adding Phong Nua, the blend of herbs not only enhances the taste but also improves the aromatic and health benefits.

Traditionally, this product recipe varied by area in the northeast, which was due to different locally available herbs and techniques learned over the centuries. The Phong Nua produced by the WCE is a bright green powder made from 13 species of indigenous herbal plants such as Sauropus androgynus (L) Merr., Moringa oleifera Lam., Morus alba L., Acacia concinna (Willd.) DC., Tiliacora triandra (Colebr.) Diels, and Albizia myriophylla Benth.

\section{MATERIAL AND METHODS}

An inspection of hygiene and manufacturing practices in the WCE was conducted by the researchers and inspectors from ALRO, SNPALRO, and SNPPHO as follows: 


\section{A. Situation Analysis}

A multidisciplinary team visited the WCE leader's home. The home is adapted for WCE processing plant. The team conducted interviews and an inspection to obtain information on their hygiene and manufacturing practices. The team comprised three researchers from the ALRO and the SNPALRO, two GMP inspectors from the SNPPHO, and the leader and 12 main staff members from the WCE.

For a research tool, we employed a checklist based on a Thai GMP standard in the Notification of Ministry of Public Health Number 193 B.E. 2543. The WCE processing plant was assessed for its GMPs under the following six sections set by the Thai FDA: (a) Plant site and production house/building; (b) Machine and equipment; (c) Production process and control; (d) Sanitation conditions; (e) Maintenance and cleaning programs; and (f) Personal hygiene.

Each item in the six sections of the checklist was weighted to reflect its major and minor corrective measures. A status of "compliance" consisted of two values: 2 points (when the requisite was fully adhered to) and 1 point (when the requisite was moderately adhered to). In addition, a status of "non-compliance" consisted of one value: 0 points (when the requisite was partially adhered to or not at all). The percentage of compliance and non-compliance factors per inspected section was calculated. The inspection culminated in a report detailing the results of the manufacturing plant status regarding the GMP standard [9].

\section{B. Product Analysis}

At least four retail packages of the product were sampled by inspectors from the SNPPHO, and they were sent to the Regional Medical Sciences Center, Udonthani, Department of Medical Sciences, the MOPH, for microbiological analysis (total aerobic plate count, yeast, and mold).

\section{Brainstorming and Development of an Action Plan for Good Manufacturing Practice Implementation}

We presented and discussed the situation analysis and product analysis reports with each responsible sector, which were then presented to the WCE leader and main staff members. The purposes were to brainstorm and obtain feedback and full support from every stakeholder. For GMP implementation, the list of non-compliance factors and priorities was discussed with all sectors involved in the WCE before corrective measures were taken.

\section{Timeframe}

This study was conducted from June 1, 2010 to July 15, 2010 .

\section{RESUlTS AND DisCUSSION}

\section{A. Situation Analysis}

We evaluated 67 items based on the six sections of the GMP requirements. The evaluation results of the WCE processing plant indicated an average of $44.02 \%$ compliance, which failed to pass the GMP standard set by the Thai FDA (60\% of the assessment). Among the six sections (Table I), machine and equipment had the highest percentage of non-compliance, followed by the five sections of plant site and production house/building, sanitation conditions, maintenance and cleaning programs, personal hygiene, and production process and controlling, in that order. A list of certain major non-compliance factors derived from the assessment is shown in Table II. We noted that several non-compliance factors found may be posed a great risk to food safety.

TABLE I: PERCENTAGE OF COMPLIANCE AND NON-COMPLIANCE FACTORS FOUND IN THE WCE PROCESSING PLANT

\begin{tabular}{lc}
\hline \hline Section & Compliance (\%) \\
\hline 1. Plant site and production house/building & 35.53 \\
2. Machine and equipment & 31.25 \\
3. Production process and controlling & 66.67 \\
4. Sanitation condition & 41.67 \\
5. Maintenance and cleaning programs & 42.31 \\
6. Personal hygiene & 46.67 \\
\hline Average & 44.02 \\
\hline \hline
\end{tabular}

The WCE faced difficulties because it does not have a suitable manufacturing site. The WCE leader's home is adapted for a processing plant, which means that the product is being produced in an inadequate location. Holes in the walls and on the roofs could lead to the accumulation of dirt and foreign objects from the external environment. The presence of domestic animals such as cats and dogs was also observed. Animals are vectors of several microorganisms, which are food-borne pathogens.

Unclean machines and improper utensils were found, such as rust on a packing machine, a wooden cutting board, and dirt in a drying oven. The wooden utensils can easily be contaminated with mold [10]. Moreover, drying raw materials in an oven lacking temperature and time control dials was found to cause under- and over-processing during the drying process. The provision of hand-washing facilities such as basins and soap is crucial to ensure hygienic practices of food handlers [11]. Therefore, the absence of basins and soap in the WCE processing area may negatively impact food safety (Table II).

In the herbal seasoning production process, most home cooking utensils were regularly, adequately, and easily cleaned. However, maintenance and cleaning problems were found in more complex equipment such as the drying oven and grinder. Another important criterion is personal hygiene. The non-compliance factors found in this section were the absence of hair restraints and gloves and the wearing of jewelry in the packing area. These problems were not too difficult to solve because this WCE has only 31 members. A lack of formal hygiene training was a more serious problem. We found a significant negative relation between knowledge and practices [12]. Because of a lack of relevant knowledge, the WCE members may be preparing their product in an explicitly unhygienic location.

\section{B. Product Analysis}

The total aerobic plate count, yeast, and mold results were obtained from the Regional Medical Sciences Center, Udonthani Province, Department of Medical Sciences, the MOPH (Table III). The results from all microbiological analyses were found to have passed the standard of the Department of Medical Sciences [13]. 
TABLE II: NON-COMPLIANCE FACTORS FOUND IN THE WCE PROCESSING PLANT

\begin{tabular}{|c|c|c|}
\hline Section & Requirements & $\begin{array}{l}\text { Non-compliance } \\
\text { factors }\end{array}$ \\
\hline \multirow[t]{4}{*}{$\begin{array}{l}\text { 1. Plant site and } \\
\text { production } \\
\text { house/building }\end{array}$} & $\begin{array}{l}\text { Separate production area } \\
\text { from a residential or } \\
\text { commercial compartment }\end{array}$ & $\begin{array}{l}\text { - Use of a house as a } \\
\text { processing plant }\end{array}$ \\
\hline & $\begin{array}{l}\text { Floors, walls, and roof in } \\
\text { good state of } \\
\text { conservation, with a } \\
\text { smooth and adequate state } \\
\text { of cleanliness }\end{array}$ & $\begin{array}{l}\text { - Cracked floor, } \\
\text { lacking sealing } \\
\text { cement and holes in } \\
\text { the walls and on the } \\
\text { roof }\end{array}$ \\
\hline & $\begin{array}{l}\text { Ventilation and air } \\
\text { circulation capable of } \\
\text { guaranteeing an } \\
\text { environment free of vapor } \\
\text { and suspended particles }\end{array}$ & $\begin{array}{l}\text { - Absence of } \\
\text { acclimatized sectors } \\
\text { and inappropriate } \\
\text { ventilation in the } \\
\text { production area }\end{array}$ \\
\hline & $\begin{array}{l}\text { Implement pest control } \\
\text { protocols }\end{array}$ & $\begin{array}{l}\text { - Lack of protocol and } \\
\text { presence of domestic } \\
\text { animals }\end{array}$ \\
\hline \multirow[t]{2}{*}{$\begin{array}{l}\text { 2. Machine and } \\
\text { equipment }\end{array}$} & $\begin{array}{l}\text { Well maintained, with no } \\
\text { rust and all exposed } \\
\text { surfaces requiring } \\
\text { corrosion/erosion } \\
\text { resistance }\end{array}$ & $\begin{array}{l}\text { - Presence of } \\
\text { cobwebs, dust, rust, } \\
\text { and mold, and } \\
\text { equipment made of } \\
\text { wood }\end{array}$ \\
\hline & $\begin{array}{l}\text { Designed for easy access } \\
\text { for cleaning }\end{array}$ & - Inappropriate design \\
\hline $\begin{array}{l}\text { 3. Production } \\
\text { process and } \\
\text { controlling }\end{array}$ & $\begin{array}{l}\text { Establish proper } \\
\text { production control } \\
\text { procedures }\end{array}$ & $\begin{array}{l}\text { - No temperature and } \\
\text { time control in dials in } \\
\text { drying process }\end{array}$ \\
\hline \multirow[t]{2}{*}{$\begin{array}{l}\text { 4. Sanitation } \\
\text { condition }\end{array}$} & Toilet facility cleanliness & $\begin{array}{l}\text { - Unsanitary } \\
\text { conditions }\end{array}$ \\
\hline & $\begin{array}{l}\text { Adequate hand-washing } \\
\text { facilities in the production } \\
\text { area }\end{array}$ & $\begin{array}{l}\text { - Absence of basins, } \\
\text { soap and disinfectant } \\
\text { liquid }\end{array}$ \\
\hline $\begin{array}{l}\text { 5. Maintenance and } \\
\text { cleaning programs }\end{array}$ & $\begin{array}{l}\text { Equipment and utensil } \\
\text { cleanliness }\end{array}$ & $\begin{array}{l}\text { - Absence of regular } \\
\text { cleaning }\end{array}$ \\
\hline \multirow[t]{2}{*}{ 6. Personal hygiene } & $\begin{array}{l}\text { Wear protective apparel } \\
\text { and avoid wearing jewelry }\end{array}$ & $\begin{array}{l}\text { - Absence of hair nets, } \\
\text { gloves, and wearing } \\
\text { jewelry }\end{array}$ \\
\hline & $\begin{array}{l}\text { Formal hygiene or } \\
\text { sanitation training }\end{array}$ & - Lack of training \\
\hline
\end{tabular}

TABLE III: Microbial QuALITy OF THE HERBAL SEASONING PRODUCT (PHONG NUA) PRODUCED BY THE WCE

\begin{tabular}{cccc}
\hline \hline Microbial quality & Standard $^{\mathrm{b}}$ & Product & Status \\
\hline $\begin{array}{c}\text { Total aerobic plate count } \\
(\mathrm{CFU} / \mathrm{g})^{\mathrm{a}}\end{array}$ & $\leq 1 \times 10^{6}$ & $1.2 \times 10^{5}$ & Pass \\
\hline $\begin{array}{c}\text { Yeast } \\
(\mathrm{CFU} / \mathrm{g})\end{array}$ & $\leq 1 \times 10^{4}$ & $<10$ & Pass \\
\hline $\begin{array}{c}\text { Mold } \\
(\mathrm{CFU} / \mathrm{g})\end{array}$ & $\leq 500$ & 50 & Pass \\
\hline \hline
\end{tabular}

${ }^{a} \mathrm{CFU} / \mathrm{g}$ is colony-forming units per gram.

${ }^{\mathrm{b}}$ Standard of the Department of Medical Sciences, 1993.

\section{Brainstorming and Development of an Action Plan for Good Manufacturing Practice Implementation}

Based on the results of situation analysis and product analysis, the action plan was conducted on the WCE processing plant to identify requirements for GMP implementation. After brainstorming with all the stakeholders, including three researchers from the ALRO and the SNPALRO, two GMP inspectors from the SNPPHO, and the leader and 12 main staff members from the WCE, the following corrective actions were determined as requirements:

1) Resolution of non-compliance factors found at the WCE site, especially regarding the processing plant structure, the location, and basic facilities such as toilet and hand-washing facilities

2) Production process control

3) GMP Training

The action plan was developed to address each non-compliance factor found during the assessment. Each non-compliance factor was also delegated to each stakeholder for action and implementation. An example of the action plan is shown in Table IV.

TABLE IV: EXAMPLE OF ACTION PLAN DEVELOPED FOR EACH NON-COMPLIANCE FACTORS FOUND IN THE ASSESSMENT

\begin{tabular}{ll}
\hline $\begin{array}{l}\text { Non-compliance factor of Section } 6^{\text {a }} \\
\text { (Lack of hygiene training) }\end{array}$ & Details of developed action plan \\
\hline $\begin{array}{l}\text { Section } 6 \\
\text { What }\end{array}$ & GMP training \\
Where & WCE premise \\
Why & To enhance \\
& GMP knowledge and practices \\
How & Provide formal GMP training for all \\
& WCE members \\
Who & ALRO, SNPALRO, \\
& SNPPHO \\
When & Immediate \\
\hline${ }^{a}$ Section 6 is pers.
\end{tabular}

${ }^{\mathrm{a}}$ Section 6 is personal hygiene.

This paragraph presents an example of the roles played by some stakeholders in executing the action plan. For example, the responsibility of collaborative GMP training will be shared by the ALRO, SNPALRO, and SNPPHO. The SNPALRO will use the information from this study, and will then propose the GMP training project to the ALRO. This proposal will be a request for financial support for project implementation. The ALRO will consider the proposal and present it to the MOAC for approval. The MOAC will allocate the budget through the ALRO, which will then be transferred to the SNPALRO. After receiving financial support, the SNPALRO will coordinate with the SNPPHO to provide GMP specialists. The SNPALRO will coordinate with the WCE leader to encourage all WCE members to participate in the project. The ALRO will join the project as an observer for information collection. This project will be a part of a strategic framework concerning GMP implementation for other food community enterprises located in the land reform area.

\section{CONCLUSION}

This study demonstrated that the WCE did not reach the GMP standard set by the Thai FDA. For GMP implementation, the collaboration of every stakeholder is crucial. The action plan will be executed by scientific and technically relevant coordinators with access to financial, physical, and human resources. An effective system must be determined based on the commitment and efficiency of each stakeholder. The GMP implementation for the WCE ensures product safety, and also enhances consumer trust in the product, in addition to providing good quality for a good 
price.

\section{ACKNOWLEDGMENT}

This study was financially supported by the Agricultural Land Reform Office (ALRO) and the Ministry of Agriculture and Cooperatives (MOAC).

\section{REFERENCES}

[1] L. Jonjoubsong, "An integrated knowledge management model for community enterprises: a case study of a rural community enterprise in Thailand," Ph.D. dissertation, Victoria University of Wellington, Wellington, New Zealand, 2008.

[2] P. Walaisatian, The Survey on Community Enterprise Knowledge, Bangkok, Thailand: Thammasart University, Department of Community Development, Faculty of Social Work, 1996.

[3] M. Baş, A. Ş. Ersun, and G. Kivanç, "Implementation of HACCP and prerequisite programs in food businesses in Turkey," Food Control, vol. 17, pp. 118-126, February 2006.

[4] FAO and WHO, "Foodborne diseases: Situation of diarrheal diseases in Thailand," in FAO/WHO Regional Conference on Food Safety for Asia and the Pacific, Seremban, Malaysia, 2004.

[5] FAO and WHO. (2006). FAO/WHO guidance to governments on the application of HACCP in small and/or less-developed food businesses. [Online]. Available: http://www.who.int/foodsafety/publications/fs_management/HACCP_ SLDB.pdf

[6] Secretariat Office of Community Enterprise Promotion Board. (2008). Interesting information about SMCEs, Thailand. [Online]. Available: $\mathrm{http}: / /$ smce.doae.go.th/ProductCategory/สรุปผลการจดทะเบียนวิสาหกิ จชุมชน-30ธค.51.pdf (in Thai)

[7] V. Chavasit, S. Kunhawattana, and W. Jirarattanarangsri, "Production and contamination of pasteurized beverages packed in sealed plastic containers in Thailand and potential preventive measures," Food Control, vol. 17, pp. 622-630, August 2006.
[8] M. Hongsawong, "North Eastern Thai herbs: local wisdom application for conservation made by Khong River community," European Journal of Social Sciences, vol. 23, pp. 474-482, 2011.

[9] Thai Food and Drug Administration (Thai FDA). (2000). Notification of Ministry of Public Health number 193 (B.E. 2543), good manufacturing practices. [Online]. Available: http://newsser.fda.moph.go.th/food/file/Laws/Notification\%20of\%20Mi nistry\%20of\%20PublicHealth/Law03P193.pdf

[10] M. Letho, R. Kuisma, J. Määtta, H. R. Kymäläinen, and M. Mäki, "Hygienic level and surface contamination in fresh-cut vegetable production plants," Food Control, vol. 22, pp. 469-475, March-April 2011.

[11] WHO. (1996). Essential safety requirements for street-vended foods. [Online]. Available: http://www.who.int/foodsafety/publications/fs_management/en/street vend.pdf

[12] A. Wilcock, M. Pun, J. Khanona, and M. Aung, "Consumer attitudes, knowledge and behavior: a review of food safety issues," Trends in Food Science and Technology, vol. 15, pp. 56-66, February 2004.

[13] The Department of Medical Sciences, Ministry of Public Health (1993). The notification of the Department of Medical Sciences (B. E 2536), microbiological quality criteria for food, utensils and food handlers. [Online]. Available: http://www.dmsc.moph.go.th/webroot/BQSF/File/VARITY/dmscguid eline.pdf

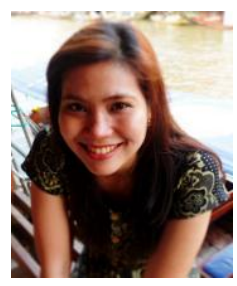

Sudarin Rodmanee was born in Bangkok, Thailand on November 1, 1980. Finished Bachelor of Biotechnology, 2002, Kasetsart University, Bangkok, Thailand. Master of Food Science, National Pingtung University of Science and Technology, Pingtung, Taiwan. In present, Ph.D. Candidate on Agribusiness at Department of Tropical Agriculture and International Cooperation, National Pingtung University of Science and Technology, Pingtung, Taiwan. She is a Researcher at Research and Planning Bureau, Agricultural Land Reform Office, Ministry of Agriculture and Cooperatives, Thailand. Her research interest is agribusiness, community enterprise, public health and food safety. 